\title{
THE INTERCONNECTEDNESS OF SPIRITUALITY AND SOCIAL DEVELOPMENT: THEMES FOR EDUCATION
}

\section{Raisuyah Bhagwan}

\section{THE HISTORICAL CONTEXT}

Spirituality, social development and social work are not antithetical to each other. The profession's earliest roots lie in the rich Judeo-Christian heritage (Leiby, 1985; Siporin, 1986). The Christian biblical command to love one's neighbour was translated into a sense of moral responsibility for social service and inspired the development of philanthropy and charity organisations during the $19^{\text {th }}$ century (Elliott, 1993; Furman, 1994). It was through the vehicles of religious organisations that social helpers sought to establish orphanages, hospitals and schools, the values of the temple and church remaining dominant influences throughout the early years (Holland, 1989).

The use of friendly visitors whose task it was to help people in poverty evolved into social helping and led to the emergence of the profession abroad (Mayadas \& Elliott, 2001). During this period voluntary social services and governmental social welfare-related policies were influenced primarily by these Christian and Jewish conceptions of charity and community responsibility (Netting, Thibault \& Ellor, 1990). In South Africa social work evolved as a result of the poor white problem, with religious organisations such as the Dutch Reformed Church taking the lead in ameliorating their plight (Noyoo, 2000).

A huge number of charitable organisations emerged in the United Kingdom, Europe, the US and later in Australia that led to the profession's focus on social casework. In these countries the move of the rural poor into the industrialising cities gave birth to the settlement movement which arose to bring the middle class into contact with the poor. Activities were arranged in urban areas to "inculcate moral values and reform the habits of slum dwellers" (Midgley in Cox \& Pawar, 2006:4). According to Leighninger and Midgley (in Cox \& Pawar, 2006) it was the settlement movement that led the fledgling profession to explore the causes of social problems particularly at both the government and community levels.

Social Darwinism also emerged to propagate biological rationalisations of inequality. It attributed negative social conditions to individual flaws thus absolving society of responsibility for the poor and underprivileged. These beliefs were challenged by the progressive and social gospel movements, which spoke of the "fulfilment of Christ's promise of heaven on earth through expansion of human cooperation and the creation of a collectivist society that would abolish poverty and capitalism" (Simon in Tangenberg, 2005:197). In the local context apartheid was conceived to perpetuate divisions along racial lines and served to distance the state from responsibility towards those most disadvantaged (Noyoo, 2000). It was the vociferous struggle of many that led to the death of this regime.

The early $20^{\text {th }}$ century marked the journey from social helping to professional social work and a rise in secularism in the international context. Scientific perspectives were adopted in order to professionalise and legitimise social work ideologies and institutions, and to align them with the prevailing medical model (Constable, 1983; Sheridan, Wilmer \& Atcheson, 1994). University social work programs emerged to further establish a professional base of scientific knowledge and methods (Canda \& Furman, 1999). Spiritual and religious perspectives, however, continued to influence social work with religious organisations such as Catholic 
Social Services and Jewish Family Services settlement house workers conveying spiritual values of service and dignity, whilst avoiding association with organised religion (Canda \& Furman, 1999; Stebner in Tangenberg, 2005). In South Africa social work education emerged in the early 1930s (McKendrick, 1998) and aligned itself with scientism and European and American models of practice (Noyoo, 2000). Social work remained disconnected from spirituality in its effort to gain professional status, the apartheid state continuing to define the parameters of social welfare policy and social work practice and education (Bhagwan, 2002).

Internationally the $20^{\text {th }}$ century was characterised by community organising, political advocacy (Tangenberg, 2005) and a move towards the social development paradigm. There was also a passionate rekindling of interest in spirituality in the United States (Bhagwan, 2002). The changing political landscape locally spurred changes and enabled the move towards a social development paradigm in South Africa. With regard to spirituality, silence continued to prevail, with only a few writers acknowledging its salience to practice and education. (Kasiram, 2006; Sacco, 1996). Meanwhile momentum continued to build around spirituality in America (AlKrenawi \& Graham, 2000; Sahlein, 2002), with persuasive arguments being made for its infusion into the educational domain (Hodge, 2005).

\section{AIM OF THE PAPER}

Despite the burgeoning discourse around spirituality in America (Sheridan, Bullis, Adcock, Berlin, \& Miller, 1992; Sheridan \& Amato-von-Hemert, 1999), only a few scholars have delineated its relatedness to social development (Chile \& Simpson, 2004; David, 2000; Woodruff, 1996). This paper adds to their work by locating spirituality within social development. Moreover, it narrows the wide chasm between spirituality and social work locally. It begins by defining religion and spirituality and then moves to illumine its interconnectedness with social development. It does this through a review of pertinent literature and by identifying the synergistic themes between spirituality and social work. It concludes by providing a summary of spiritual themes that can be integrated into education.

\section{BACKGROUND TO THE PAPER}

Some of the "spirituality" themes identified for education were drawn from a qualitative analysis of 22 American courses on spirituality and social work. This was in accordance with the objectives of a doctoral study that focused on curricula development on spirituality and social work in South Africa. The interconnectedness to social development has been developed through a literature study on spirituality and social development. Content analysis was used to analyse both the American curricula and pertinent literature. Content analysis is the process of "careful, detailed, systematic examination and interpretation of a particular body of material in an effort to identify patterns, themes ... and meanings" (in Berg, 2007:304).

\section{DEFINITIONS OF RELIGION AND SPIRITUALITY}

The literature is coloured by a myriad of definitions of religion and spirituality. Although precise conceptualisations of these terms are elusive, both are seen as distinct, although interrelated, overlapping constructs (Bhagwan, 2002; Hodge, 2005). Religion has been defined as a "societal phenomenon, involving social institutions with rules, rituals, covenants, and formal procedures" (Thoresen, Harris \& Oman, 2001:22), whilst "the spiritual quest although often clothed in religion, is felt to be an utterly personal experience, not reliant on institutional affiliation and involvement" (Sperry \& Shafranske, 2005:15). 
For Ochs (in Faver, 2004:242) spirituality is “...relatedness which involves connections not only with a sacred other, but also with other people and perspectives and with a source of meaning beyond oneself". Similarly Canda and Furman (1999:309) wrote that "...individual spirituality grows in the field of community, family and friends; religious institutions or nonsectarian spiritual social groups; neighbourhoods and cities; cultures and nations; ecosystems of plants, animals, stones, air, sunlight, moonlight, and clouds; the planet earth; the cosmos; and perhaps as many believe communities of spiritual beings".

Faver (2004:242) spoke of relational spirituality, saying that it is the "insight of interconnectedness" i.e. through relationships we are all connected to everything. As we grow through a sense of connection and responsibility with others and other beings, we search for ways to help and heal the world and ourselves (Canda \& Furman, 1999). This awareness of being connected to everything can also be a spiritual awakening that constitutes a foundation for action against all forms of exploitation (Coates, 2004). Spiritually sensitive practice is thus an expression of compassion, which literally means passion with others (Canda \& Furman, 1999). It is within these conceptualisations of spirituality that social development finds its niche. The historical journey and current philosophy of social development as it relates to spirituality is discussed in the following section.

\section{SOCIAL DEVELOPMENT AND SPIRITUALITY}

The social development literature has its own historical trail, which began with an emphasis on economic growth, followed by a move to social and institutional change (Gray, Mazibuko \& O'Brien, 1996). Early conceptualisations of social development focused on its being (a) a multifaceted macro-perspective aimed at empowering and building the capacity of communities and societies to meet social needs and to develop social resources; and (b) a social intervention which harmonised itself with economic development efforts (Jones, 1981; Midgley in Marie, 1996).

In the past decade, however, the focus of social development has moved beyond the sociopolitical, cultural and structural development that occurs in the milieu of communities, social institutions and societies, to socio-emotional, moral or intellectual development that allows for the expansion of competencies and search for new, socially responsible experiences at an individual level (Billups, 1990). The awareness that to dichotomise the micro-perspective from the macro-perspective was fundamentally flawed led to a call for both facets to be articulated as social development. In this vein the Centre for the Study of Social Policy in Stanford, advanced two ethics, viz. the self-realisation ethic and the ecological ethic. Both emphasise that the "total community of life-in-nature and the oneness of the human race ... are not contradictory but complementary" (in Billups, 1990:16).

It is in this vein that Faver's (2004:242) spiritual "insight of interconnectedness" comes to life and that the synergies between both paradigms are illuminated. To expand this notion further Table 1 is used to interweave the synergies between the values, concepts, principles and strategies between spirituality and social development. As indicated in the background to this paper, the interconnectedness reflected in Table 1 emerged after a literature study on spirituality and social work. As is reflected in the Table, both paradigms are based on values of human dignity, equality, social justice and peace (Bhagwan, 2002; Omer, 1979). They are also both concerned with the poor and the homeless, children and families, ethnic minority groups, those with mental health disorders, women, the elderly and other oppressed or vulnerable groups. Perhaps the most critical synergy lies in the fact that both transcend residual and 
institutional approaches to enable higher levels of social functioning and human realisation (Midgley, 1995).

TABLE 1

THE INTERCONNECTEDNESS BETWEEN SPIRITUALITY AND SOCIAL DEVELOPMENT

\begin{tabular}{|c|c|c|}
\hline \begin{tabular}{|c|} 
INTERCONNECTING \\
THEMES
\end{tabular} & SOCIAL DEVELOPMENT & SPIRITUALITY \\
\hline Approach & $\begin{array}{l}\text { Integrative, inclusive, multi- } \\
\text { sectoral and multidisciplinary } \\
\text { approach which focuses on } \\
\text { individual and social change } \\
\text { and development (Gray, } \\
\text { 1997a, b). }\end{array}$ & $\begin{array}{l}\text { Holistic approach which focuses on } \\
\text { building strength and resilience, } \\
\text { psycho-spiritual and transpersonal } \\
\text { growth and development so as to } \\
\text { promote, restore, maintain and } \\
\text { enhance wellbeing of individuals, } \\
\text { families, social groups, } \\
\text { organisations and communities } \\
\text { (Bhagwan, 2002; Gotterer, 2001). }\end{array}$ \\
\hline Principles & $\begin{array}{l}\text { Equality, respect for human } \\
\text { rights, cultural diversity, } \\
\text { social transformation, } \\
\text { humanism, interdependence, } \\
\text { non-discrimination (Gray, } \\
\text { 1997a, b; Woodruff, 1996). }\end{array}$ & $\begin{array}{l}\text { Care and respect for humankind } \\
\text { regardless of human and cultural } \\
\text { diversity, dual responsibility to } \\
\text { serve clients and broader society in } \\
\text { an ethical and peaceful way; pursue } \\
\text { social change with and on behalf of } \\
\text { vulnerable/oppressed groups } \\
\text { (Bhagwan, 2002). }\end{array}$ \\
\hline Concepts/values & $\begin{array}{l}\text { Social justice, human dignity } \\
\text { and rights, empowerment, } \\
\text { fulfilment of basic needs, } \\
\text { participatory democracy and } \\
\text { peace (Bernstein, 1995; Gray, } \\
\text { 1992; Marie, 1996). }\end{array}$ & $\begin{array}{l}\text { Justice, peace, human dignity, } \\
\text { compassion (Bullis, 1996; Canda \& } \\
\text { Furman, 1999). }\end{array}$ \\
\hline Target groups & $\begin{array}{l}\text { All groups but give priority to } \\
\text { the most vulnerable, needy, } \\
\text { disenfranchised, unemployed } \\
\text { women, and children, those } \\
\text { living in rural areas (Neilson } \\
\& \text { Gray, 1997). }\end{array}$ & $\begin{array}{l}\text { All humankind, but is concerned } \\
\text { with the poor, homeless, children } \\
\text { and families, ethnic minority } \\
\text { groups, those with mental } \\
\text { disorders, women, the elderly, } \\
\text { oppressed/vulnerable groups } \\
\text { (Bullis, 1996; Netting et al., 1990). }\end{array}$ \\
\hline Strategies & $\begin{array}{l}\text { Individual intervention, } \\
\text { community development } \\
\text { building, social education and } \\
\text { action/reform, conscientisa- } \\
\text { tion, empowerment, heuristic } \\
\text { research approaches. Uses a } \\
\text { multi-system, } \\
\text { interdisciplinary holistic } \\
\text { approach (Gray, 1997a, b). }\end{array}$ & $\begin{array}{l}\text { Psycho-social and spiritual } \\
\text { transformation, creating multi- } \\
\text { cultural groups; working } \\
\text { collaboratively with traditional } \\
\text { healers and spiritual leaders; } \\
\text { spiritual research approaches } \\
\text { (Bhagwan, 2002; Canda \& Furman, } \\
\text { 1999). }\end{array}$ \\
\hline
\end{tabular}




\begin{tabular}{|c|c|c|}
\hline $\begin{array}{c}\text { INTERCONNECTING } \\
\text { THEMES }\end{array}$ & SOCIAL DEVELOPMENT & SPIRITUALITY \\
\hline Levels/systems & $\begin{array}{l}\text { Levels: } \\
\text { Micro-: individual, family and } \\
\text { small group; mezzo-: village } \\
\text { and community; macro-: } \\
\text { national, global. } \\
\text { Systems: social, economic, } \\
\text { political, socio-cultural, } \\
\text { religious/scientific (Gray, } \\
\text { 1997a, b). }\end{array}$ & $\begin{array}{l}\text { Levels: } \\
\text { Micro-: individual, family and } \\
\text { small group; mezzo-: village and } \\
\text { community; macro-: national, } \\
\text { global. } \\
\text { Systems: social, economic, } \\
\text { political, socio-cultural, } \\
\text { religious/scientific (Canda \& } \\
\text { Furman, 1999). }\end{array}$ \\
\hline Resources & $\begin{array}{l}\text { Social resources are referred } \\
\text { to as non-material resources, } \\
\text { e.g. people's participation, } \\
\text { community support and } \\
\text { naturally occurring networks, } \\
\text { which are important for } \\
\text { community organising and } \\
\text { capacity building. }\end{array}$ & $\begin{array}{l}\text { Inherent strengths and resiliencies } \\
\text { of individuals (Saleebey, 1997), } \\
\text { spiritual strengths (Hodge, 2005); } \\
\text { religious/spiritual groups and } \\
\text { organisations; } 12 \text { step programmes } \\
\text { (Bullis \& Harrigan, 1992). }\end{array}$ \\
\hline Outcomes & $\begin{array}{l}\text { Socio-economic development } \\
\text { for individuals, communities } \\
\text { and the nation (Woodruff, } \\
\text { 1996). }\end{array}$ & $\begin{array}{l}\text { Psycho-social and spiritual } \\
\text { transformation for individuals, } \\
\text { families and communities (Canda } \\
\text { \& Furman, 1999). }\end{array}$ \\
\hline
\end{tabular}

\section{SPIRITUALITY AND SOCIAL DEVELOPMENT: SYNERGISTIC PARTNERS}

Social development philosophy embraces a holistic, integrated, unified approach, which views each individual person and all persons as interrelated and interdependent parts of a larger intersystem (Paiva, 1977). Quoting Maas, Billups (1990) said that it is these intricate interdependencies between people individually and collectively that make it possible to sustain a caring and sharing society. Chile and Simpson (2004) argued that within a spiritual context inner peace cannot be separated from the world. Spiritual approaches embrace social justice issues, economic fairness, human rights and ecological sustainability and require a harmonising of individual and collective needs. Writing within a social development context, David (2000:9) contends that "transformation involves both material and spiritual changes ... Transformation is intended to (1) enable persons to become fully human; (2) change economic and social relations to conform to justice and freedom; and (3) transform material and spiritual dimensions of life into a joint enterprise". When individual's spirituality increases so does the connection to community and social responsibility (Damianakis, 2006).

Canda and Furman (1999), proponents of spiritually sensitive practice, elucidate a range of interventions that can nurture social development. Some activities explicated to achieve a more socially and spiritually developed universe include cooperation with traditional healers; collaboration with religious communities and spiritual support groups; developing and using multicultural teams; prayer; creating spiritually sensitive administrative approaches; dialogue across spiritual perspectives; enabling family and community rituals and ceremonies; developing strategies to redress poverty and justice issues; lobbying and social activism by religious groups; win-win solution making; exploring sacred stories, symbols and teachings of 
spiritual communities; advocacy for spiritual sensitivity in health and social service policy; developing mutually beneficial human-nature relationships; individual psycho-spiritual transformation and nature retreating.

Although social workers may be unaware of church-based services and consequently do not engage with them (Amato-von-Hemert, 1994), collaboration and partnerships between practitioners, clergy and other spiritual leaders may richly support intervention with individuals and families (Bullis \& Harrigan, 1992; Bullis, 1996). Religious congregations or organisations form an important network in the provision of a range of social services in rural, urban and suburban communities (Amato-von-Hemert, 1994; Evans, 1992; Netting et al., 1990; Netting, 1982). Such services include soup kitchens, homeless hospitality centres and shelters, home health care, social and recreational programmes, spiritual education and guidance and other crisis-intervention services related to the aged, ill and physically challenged and those with AIDS. For Sinha et al. (in Tangenberg, 2005:199) "it is the spiritual strength" which dwells within these community- and congregation-based efforts that form the basis of such services.

Organised religious groups also serve as a catalyst for social change at the organisational, community and policy levels and influence public discourse and decision-making in a range of areas such as sexuality, poverty, health care, civil rights and education (Sheridan \& Amatovon-Hemert, 1999). It is the deep links between spirituality, empowerment and social justice in groups whose religious traditions provide cultural identity and support that create the impetus for change (Guitierrez \& Lewis in Tangenberg, 2005). Religious organisations also act as powerful social institutions with an ability to vigorously motivate and sustain political action through committed participants (Wood in Tangenberg, 2005).

Although spirituality is thus a natural ally in social development, there is little in the literature which reflects this strength. A journey into the literature reveals many publications on social development in the South African context, but none which connect social development to spirituality (Gray et al., 1996; Gray, 1997; Lombard, 2000). The prevailing void in the literature with regard to spirituality characterises social work education as well. A scrutiny of the exit-level outcomes for Social Work (BSW), NQF Level 7 reveals no reference to religion or spirituality, although elements of them may be couched in the following outcomes: " 9 . Demonstrate social work values while interacting with human diversity; 14. Analyse human behaviour with regard to the intersections of race, class, culture, ethnicity, gender" (Lombard, Grobbelaar \& Pruis, 2003:12-13).

The section that follows acknowledges the void in the literature and training, and argues for the infusion of spirituality into social development education.

\section{EDUCATION AND TRAINING}

Scholars such as Sanders (in Billups, 1990) have challenged the social work profession to expand its vision, arguing that to be responsive to humanising development, it is necessary for education and practice to be radically restructured. Since the birth of the social development paradigm most schools of social work have begun to infuse it vigorously into social work curricula locally and abroad (Gray et al., 1996; Midgley, 1994). Spirituality, however, has continued to remain at a profound distance in social work education, particularly in South Africa. because of the synergies between both paradigms, opportunities to interweave spirituality into social development education is definitely possible. A qualitative analysis of courses which offer spirituality and social work $(\mathrm{N}=22)$ in the US (Bhagwan, 2002) reveal that 
content on social development aspects, e.g. social policy, cross-cultural aspects, ethics, community work, has been effectively interweaved into curricula on spirituality.

Curricula analysis and a study of the literature revealed several themes that could be used to incorporate spirituality into social work/development education. The author has crystallised them into the following points that educators can utilise:

- Illuminate the theoretical underpinnings of the spiritual paradigm and how it harmonises with the social development perspective.

- Highlight the spiritual dimension as an integral facet of the person-in-environment gestalt.

- Provide conceptual clarity around the terms "religion" and "spirituality" so that the difference is clearly understood.

- Illuminate the history of organised religion and the role of religious communities in shaping the development of the social work profession and social welfare programmes/policy (Bullis, 1996; Canda \& Furman, 1999).

- Explore the historical and current role of religious/spiritual groups in both supporting and impeding social justice and reform. Explore the spiritual and transpersonal nature of social activism and social reform (Sheridan, 2000).

- Highlight the role and influence of influence of religious organisations in public discourse and decision-making in the areas of global politics, health care, poverty, education, civil rights, economic and environmental policies (Amato-von-Hemert, 1994; Netting et al., 1990).

- Identify and critically reflect upon the diversity of sectarian, non-sectarian/indigenous, and philosophical spiritual perspectives, e.g. Christian fundamentalism, Buddhism, African Traditional Religion, and their implications for social work practice. Create an understanding of the range of religious/spiritual issues as they intersect with social work issues (social development) across diverse communities.

- Create a link between spirituality and forms of human diversity, e.g. race, ethnicity/culture, gender, sexual orientation, disability, age. This would enable an exploration of services to at-risk populations (Canda \& Furman, 1999).

- Critically analyse the supportive and oppressive aspects of religious and spiritual perspectives concerning issues of human diversity such as gender, race ethnicity, sexual orientation and disability.

- Exemplify the range of spiritually sensitive social development interventions at both a micro- and macro-level, e.g. psycho-social and spiritual transformation through individual therapy; working collaboratively with traditional healers and spiritual leaders in rural settings to develop services for the poor; empowering religious organisations to influence social policies that affect vulnerable and marginalised groups (Canda \& Furman, 1999).

These themes can be used to gradually widen the lens of the spirituality paradigm in South Africa. Spirituality as it interconnects with social development and various other facets of social work can be built into and diffused across the curriculum in a holistic, integrated, multifaceted and multidimensional way. In this way spirituality is not seen as a discrete component that is linked to one dimension, but as a harmonious partner in all social work realms. 


\section{CONCLUSION}

The natural synergies between spirituality and social work enable the vision alluded to by Adams of a "Cathedral of Humanity" which is capacious enough to hold a Fellowship of common purpose, and which will "be beautiful enough to persuade men to hold fast to the vision of human solidarity" (cited by Oakley in Canda \& Furman, 1999:89). The rekindling of spirituality in contemporary social work practice and a renewed focus on a holistic approach requires that social work harmonises itself with spirituality. A critical starting point for the intertwining of these perspectives lies in education and training. This paper has illuminated the pathways to build this synergy within the curriculum by elucidating salient themes for social development education. Failure by practitioners and educators to make meaning of this synergy will reflect a fragmented social work practice bereft of the most important dimension that interconnects humankind with the universe, i.e. spirituality.

\section{ACKNOWLEDGEMENT}

The author gratefully acknowledges the assistance and support of Miss Lavisha Deonarian, Faculty of Health Sciences Research Assistant, Durban University of Technology.

\section{REFERENCES}

AL-KRENAWI, A. \& GRAHAM, J. 2000. Islamic theology and prayer: relevance for social work practice. International Social Work, 43:289-304.

AMATO-VON-HEMERT, K.A. 1994. Should social work education address religious issues? Yes! Journal of Social Work Education, 30(1):7-11.

BHAGWAN, R. 2002. The role of religion and spirituality in social work practice: guidelines for curricula development at South African Schools of Social Work. Durban: University of Natal. (DPhil Thesis)

BERG, B.L. 2007. Qualitative research methods for the social sciences $\left(6^{\text {th }}\right.$ ed $)$. Boston: Pearson Education, Inc.

BERNSTEIN, A. 1995. Redefining social work's emphasis on the "social". The path to development. International Social Work, 38:53-67.

BILLUPS, J.O. 1990. Toward social development as an organizing concept for social work and related social professions and movements. Social Development Issues, 12(3):14-26.

BULLIS, R.K. 1996. Spirituality in social work practice. Washington D.C.: Taylor and Francis.

BULLIS, R.K. \& HARRIGAN, M.P. 1992. Religious denominational policies on sexuality. Families in Society, 73(5):304-312.

CANDA, E.R. \& FURMAN, L.D. 1999. Spiritual diversity in social work practice: the heart of helping. New York: The Free Press.

CHILE, L.M. \& SIMPSON, G. 2004. Spirituality and community development: exploring the link between the individual and the collective. Community Development Journal, 39(4):318331.

COATES, J. 2004. From ecology to spirituality and social justice. Currents: New Scholarship in the Human Services, 3(1):1-11. 
CONSTABLE, R.T. 1983. Values, religion and social work practice. Social Thought, 1(7):2941.

COX, D. \& PAWAR, M. 2006. International social work: issues, strategies and programs. USA: Sage Publications.

DAVID, G. 2000. From social development to transformation. Social Development Issues, 22(1):9-14.

DAMIANAKIS, T. 2006. Seeking the spiritual in anti-oppressive organizational change. [Online] Available: http://www.criticalsocial.com/units/socialwork/critical.nsf. [Accessed: 15/12/2008].

ELLIOTT, D. 1993. Social work and social development: towards an integrative model for social work practice. International Social Work, 36:21-36.

EVANS, E.N. 1992. Liberation theology, empowerment theory and social work practice with the oppressed. International Social Work, 35:135-147.

FAVER, C.A. 2004. Relational spirituality and social care giving. Social Work, 49(2):241250.

FURMAN, L. 1994. Religion and spirituality in social work education: preparing the culturally sensitive practitioner for the future. Social Work and Christianity, 21(2):103-115.

GOTTERER, R. 2001. The spiritual dimension in clinical social work practice: a client perspective. Families in Society, 82(2):197-197.

GRAY, M. 1992. The ethical implications of a primary model of care. Social Work/Maatskaplike Werk, 25(1):44-47.

GRAY, M., MAZIBUKO, F. \& O’BRIEN, F.O. 1996. Social work education for social development. Journal of Social Development in Africa, 11(1):33-42.

GRAY, M. 1997a. A pragmatic approach to social development Part 1. Social Work/Maatskaplike Werk, 33(3):210-233.

GRAY, M. 1997b. A pragmatic approach to social development Part 2. Social Work/Maatskaplike Werk, 33(4):360-372.

HODGE, D.R. 2005. Perceptions of compliance with the profession's ethical standards that address religion: a national study. Journal of Social Work Education, 41(2):279-296.

HOLLAND, T.P. 1989. Values, faith and professional practice. Social Thought, 15(1):28-40.

JONES, J.F. 1981. Can we teach social development in a social work curriculum? International Social Work, 24(4):29-31.

KASIRAM, M.I. 2006. Hope and healing through spirituality - a meeting of minds between social work and theology. The Social Work Practitioner-Researcher, 18(2):165-173.

LEIBY, J. 1985. The moral foundations of social welfare and social work. Social Work, 30:323-330.

LOMBARD, A. 2000. Social development training and practice integrated: partnerships for transformation at grass roots level. Social Development Issues, 22(1):50-58.

LOMBARD, A., GROBBELAAR, M. \& PRUIS, S. 2003. Standards for social work qualifications in South Africa. Social Work/Maatskaplike Werk, 39(1):1-17. 
MARIE, W.O. 1996. Community building: community practice. Social Work, 41(5):481-499.

MAYADAS, N.S. \& ELLIOTT, D. 2001. Psychosocial approaches, social work and social development. Social Development Issues, 23(1):5-13.

McKENDRICK, B. 1998. Social work education and training: from preparing for apartheid society to training for a developing democracy. Social Work/Maatskaplike Werk, 34(1):99111.

MIDGLEY, J. 1994. Defining social development: historical trends and conceptual formulations. Social Development Issues, 16(3):3-19.

MIDGLEY, J. 1995. Social development: The developmental perspective in social welfare. London: Sage Publications.

NEILSON, D. \& GRAY, M. 1997. Integrating social development into child welfare services. Social Work Practice, 1:16.

NETTING, F.E. 1982. Secular and religious funding of church-related agencies. Social Service Review, 58:404-420.

NETTING, F.E., THIBAULT, J.M. \& ELLOR, J.W. 1990. Integrating content on organized religion into macropractice courses. Journal of Social Work Education, 1:15-24.

NOYOO, N. 2000. Preparing South African social workers for social development praxis. Social Development Issues, 22(1):35-41.

OMER, S. 1979. Social development. International Social Work XXII, 3:11-26.

PAIVA, J. 1977. A conception of social development. Social Service Review, 51(2):327-336.

SACCO, T. 1996. Spirituality and social work students in their first year of study at a South African University. Journal of Social Development in Africa, 11(2):43-56.

SAHLEIN, J. 2002. When religion enters the dialogue: a guide for practitioners. Clinical Social Work, 30(4):381-403.

SALEEBEY, D. (ed) 1997. The strengths perspective in social work practice $\left(2^{\text {nd }}\right.$ ed $)$. New York: Longman Publishers.

SHERIDAN, M.J., BULliS, R.K., ADCOCK, C.R., BERLIN, S.D. \& MILLER P.C. 1992. Practitioner's personal and professional attitudes and behaviours towards religion and spirituality: issues for social work education and practice. Journal of Social Work Education, 30(3):363-376.

SHERIDAN, M.J., WILMER, C.M. \& ATCHESON, L. 1994. Inclusion of content on religion and spirituality in the social work curriculum: a study of faculty views. Journal of Social Work Education, 30(3):363-376.

SHERIDAN, M.J. \& AMATO-VON-HEMERT, K. 1999. The role of religion and spirituality in social work education and practice: a survey of student views and experiences. Journal of Social Work Education, 35(1):125-141.

SHERIDAN, M.J. 2000. The "Role of Religion and Spirituality in Practice" (RRSP) Scale: psychometric information and scoring instructions $\left(3^{\text {rd }}\right.$ ed). Richmond, VA: Virginia Commonwealth University. 
174

SIPORIN, M. 1986. Contribution of religious values to social work and the law. Social Thought, 12:35-50.

SPERRY, L. \& SHAFRANSKE, E.P. 2005. Addressing the spiritual dimension in psychotherapy: introduction and overview. In: SHAFRANSKE, E.P. \&. SPERRY L. (eds) Spiritually oriented psychotherapy. USA: United Book Press Inc.

TANGENBERG, K.M. 2005. Faith-based human services initiatives: considerations for social work practice and theory. Social Work, 50(3):197-217.

THORESEN, C.E., HARRIS, A.H.S. \& OMAN, D. 2001. Spirituality, religion, and health: evidence, issues and concerns. USA: The Guildford Press.

WOODRUFF, L.K. 1996. Impediments to cooperation toward international social development: A Jungian perspective. Social Work, 41(4):383-390.

Dr Raisuyah Bhagwan, Department of Community Health Studies, Faculty of Health Sciences, Durban University of Technology, Durban, South Africa. 